\title{
AMCoR
}

Asahikawa Medical College Repository http://amcor.asahikawa-med.ac.jp/

Transactions of the Royal Society of Tropical Medicine and Hygiene (2006. Apr) 100(4):346-353.

High prevalence of Taenia saginata taeniasis and status of Taenia solium cysticercosis in Bali, Indonesia, 2002-2004

T. Wandra ; P. Sutisna ; N.S. Dharmawan ; S.S. Margono ;

R. Sudewi ; T. Suroso ; P.S. Craig ; A. Ito 


\section{High prevalence of Taenia saginata taeniasis and status of Taenia solium cysticercosis}

in Bali, Indonesia, 2002-2004

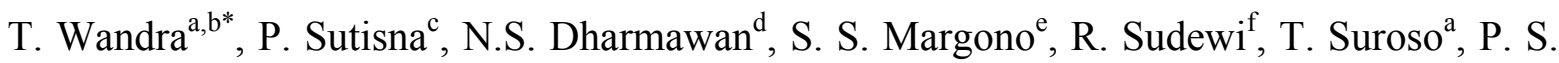
Craig $^{\mathrm{g}}$, and A. Ito ${ }^{\mathrm{b} * \#}$

${ }^{a}$ Directorate General Communicable Disease Control and Environmental Health, Ministry of Health, Jakarta, Indonesia

${ }^{\mathrm{b}}$ Department of Parasitology, Asahikawa Medical College, Asahikawa, Japan

${ }^{\mathrm{c}}$ Department of Parasitology, University of Udayana, Bali, Indonesia

${ }^{\mathrm{d}}$ Faculty of Veterinary Medicine, University of Udayana, Bali, Indonesia

${ }^{\mathrm{e}}$ Department of Parasitology, University of Indonesia, Jakarta, Indonesia

${ }^{\mathrm{f}}$ Department of Neurology, University of Udayana, Bali, Indonesia

${ }^{\mathrm{g}}$ Cestode Zoonoses Research Group, Bioscience Research Institute and School of

Environment and Life Science, University of Salford, Greater Manchester, UK

*: These authors equally contributed for this work.

\# corresponding author: Department of Parasitology, Asahikawa Medical College, Midorigaoka-Higashi 2-1-1-1, Asahikawa, Japan. Tel.: +81 16668 2420; fax: +81 16668 2429. E-mail address: akiraito@asahikawa-med.ac.jp (A. Ito) 


\section{Summary}

An epidemiological survey of taeniasis/cysticercosis was carried out in one semi-urban and two urban villages in three districts in Bali, Indonesia in 2002 and 2004. A total of 398 local people from 247 families were diagnosed by anamnesis and clinical examinations, and 60 residents were suspected to be taeniasis carriers. Among 60 suspected carriers, 56 persons expelled a total of 61 taeniid adult worms after praziquantel treatment. From 398 residents, 252 stool samples were available for analysis of taeniid eggs, copro-antigens or copro-DNA for identification of taeniid species, and 311 serum samples were available for detection of antibodies against Taenia solium cysticercosis. Taeniasis prevalences were highly variable among three villages (1.1-27.5\%) and only one cysticercosis due to $T$. solium infection was detected. All expelled tapeworms were confirmed to be Taenia saginata by mitochondrial DNA analysis. There was no Taenia asiatica human case in Bali. Case control analysis of 106 families chosen at random from 179 families in 2004 and another 106 families from non-endemic areas revealed that risk factors of $T$. saginata taeniasis for families were the level of education $(\mathrm{p}<0.01)$, the consumption of beef lawar $(\mathrm{p}<0.01)$ and the source of lawar $(\mathrm{p}<0.01)$.

KEYWORDS: taeniasis, cysticercosis, Taenia saginata, Taenia solium, Taenia asiatica, questionnaire, direct smear, corpo-ELISA, copro-DNA, mitochondrial DNA, serology, Bali, Indonesia 


\section{Introduction}

In Indonesia, there are three known endemic provinces for taeniasis/cysticercosis: Bali, Irian Jaya (Papua) and North Sumatra (Handali et al., 1997; Simanjuntak et al., 1997; Wandra et al., 2000, 2003; Margono et al., 2001; Ito et al., 2002, 2003, 2004). Taeniasis, either due to Taenia saginata and/or Taenia solium in East Nusa Tenggara and South-East Sulawesi were reported to be $7.0 \%(31 / 445)$ in 1975 (Simanjuntak et al., 1997) and 0.4\% (1/243) in 1985 (Margono et al., 2004). Other surveys where Balinese people had been resettled revealed of taeniasis rates of $1.0 \%(5 / 476)$ in Lampung and $0.4 \%(1 / 245)$ in North Sulawesi in 1981 (Simanjuntak et al., 1997; Margono et al., 2004). Cases with taeniasis and/or cysticercosis have also been reported from Jakarta, West Kalimantan, East Kalimantan and East Java (Margono et al., 2001, 2004; Suroso, 2002).

Historically, the first report of T. solium infection in pigs in Bali was published in 1928. After 32 years, one case of subcutaneous cysticercosis (SCC) in a Balinese woman was reported (quoted from Sutisna, 1989, 2002; Margono et al., 2004). There are several reports on T. solium taeniasis, epileptic seizures, SCC, neurocysticercosis (NCC), and seroprevalence of cysticercosis in Bali (Ngoerah, 1975; Sutisna, 1989, 1990, 2002; Sutisna et al., 1999, 2000; Margono et al., 2001, 2004).

Prevalence rates of T. saginata taeniasis in Bali were reported during 1977-1990 to range from $0.4-23 \%$ and were distributed in all nine districts of the island (Sutisna, 1989, 1990; Suweta, 1991; Sutisna et al., 1999, 2000; Margono et al., 2001, 2004). A more recent survey performed in Gianyar District in Bali revealed a taeniasis prevalence of $1.3 \%$ by coproantigen detection test (Sutisna et al., 1999).

The present paper indicates a resurgence of $T$. saginata taeniasis related to consumption of local raw beef dish (lawar) through inadequate inspection of meat and food hygiene, and also reports on the present situation of $T$. solium cysticercosis in Bali. 


\section{Materials and Methods}

\subsection{Field survey and sample collection}

An epidemiological survey was carried out in one semi-urban village, Ketewel (Gianyar District) in December 2002 and February 2004, and in two urban villages, Jagapati and Penatih (Badung and Denpasar Districts, respectively) in 2004. These three districts are located at the southern part of Bali Island and around and including the capital city, Denpasar. Ketewel village is just $7 \mathrm{~km}$ far east from Denpasar. The subjects voluntarily sampled were family heads and housewives and other persons $\geq 15$ years in one Banjar (=sub-village) of each village. A Banjar was selected based on the local health center reports on taeniasis, and each Banjar consisted of 159-165 families and of 782-800 inhabitants. Additional sampled populations were from the neighboring Banjar(s), where they came after the Head of Banjar informed and invited them for a free check-up or treatment. After obtaining central and local government ethical approvals, 125 serum samples and 75 stool samples from 125 residents were collected in Ketewel in December 2002; 46 serum samples and 46 stool samples from 51 residents who were not examined in 2002 came in February 2004. Additional samples were collected one year later (February 2004) from 32 taeniasis patients in Ketewel treated with praziquantel (15 mg/kg single dose, Suroso, 2000) in 2002. Ninety one serum samples and 34 stool samples from 94 residents in Jagapati, and 49 serum samples and 97 stool samples from 128 persons in Penatih were also collected in February 2004. A total of 32 T. saginata taeniasis patients were confirmed and treated in 2002 in Ketewel. Taeniasis cases were suspected by Questionnaire Responses and Demonstration of Proglottids (QRDP), and a clinical examination including abdominal symptoms and history of expulsion of proglottids. Stool examinations for detection of Taenia spp eggs (direct smears) and morphological examinations of proglottids for identification of the tapeworm were carried out at Udayana 
University, Bali. Stool samples available for coproantigen testings (copro-ELISA) were kept frozen. Stool samples for copro-DNA analysis and proglottid samples for mitochondrial (mt) DNA analysis were kept in $99.5 \%$ ethanol. Serological examination by both ELISA and immunoblot, and copro-ELISA, copro-DNA, multiplex PCR, and mtDNA sequencing were carried out at Asahikawa Medical College (Japan) in 2003 and in 2004 (Allan et al., 1992; Ito et al., 1998, 1999; Nakao et al., 2002; Yamasaki et al., 2004a, 2004b). Cysticercosis cases were suspected by questionnaires on the history of epileptic seizures, detection of subcutaneous nodule by palpation and serological examination for $T$. solium cysticercosis (Wandra et al., 2003). All tapeworms expelled from tapeworm carriers were confirmed by mtDNA analysis using cytochrome $c$ oxidase subunit I (cox1) gene to differentiate T. solium, T. saginata and T. asiatica (Yamasaki et al., 2004a, 2004b, 2004c), since proglottids of T. saginata and T. asiatica are morphologically identical (Fan 1988; Eom and Rim, 1993; Ito et al., 2003; 2004) and T. asiatica was also expected to be distributed in Bali (Dharmawan, 1998). Additional data through questionnaires from 106 family heads were also collected in a non-endemic Taenia area (Banjar) in East Denpasar Sub-District (Denpasar District) as a family control for the 106 family heads living in the taeniasis endemic area (Banjar) in Ketewel and Penatih villages. Bivariate analysis was performed using Epi Info (version 6).

\subsection{ELISA, immunoblot and copro-ELISA}

Enzyme linked immunosorbent assay (ELISA) and immunoblot were carried out using glycoproteins (GPs) from a pH 8.1 fraction purified by preparative isoelectric focusing from T. solium cysts (Rotofor, BioRad, USA) (Ito et al., 1998, 1999) and a chimeric recombinant antigen (modified from Sako et al., 2000). Detection of antibody by ELISA was performed as described by Ito et al. $(1998,1999)$ and Sako et al. (2000). Copro-ELISA 
for Taenia spp. based on the method described by Allan et al (1992) was carried out using a commercial ELISA kit according to the manufacturer's instructions (Genzyme Virotech, GmBh, Russelsheim Germany).

\subsection{Multiplex PCR and DNA sequencing}

According to Yamasaki et al. (2004a, 2004b, 2004c), mitochondrial DNA samples from stools from taeniasis cases and from expelled tapeworms were analyzed by multiplex PCR for differentiation of T. saginata, T. asiatica and T. solium using stool samples fixed in ethanol from the tapeworm carriers.

\section{Results}

\subsection{Taeniasis Survey}

Population sample size and data on T. saginata taeniasis from three villages in three districts in Bali are summarized in Table 1. A total of 60 persons among 398 local people in three villages of three districts in Bali were suspected to be T. saginata taeniasis cases by QRDP (questionnaire responses and demonstration of proglottids) and 56 taeniasis cases were confirmed after treatment. The history of expulsion of proglottids from four suspected persons who did not harbour any taeniid worms when they were treated with praziquantel was that they expelled proglottids one or two years before but no more evidence past one year. Stool samples from these four persons were negative by direct smears. So, these persons were expected to have had taeniid worms but lost them more than one year before. After QRDP, a total of 252 stool samples and 311 serum samples were obtained. A total of 15 from 252 stool samples (5.95\%) were positive by direct smears, whereas only 82 faecal samples were available for copro-ELISA, since the volume of some fecal samples were too small and no more samples were available for 
copro-ELISA after direct smear tests. Eighty-two faecal samples included seven (8.54\%) copro-ELISA positives and four direct smear positives. These direct smear positive cases were not applied for re-confirmation by copro-ELISA any more, since we had data that direct smear positive cases were all copro-ELISA positive (Wandra et al. unpublished data). So, a total of $11(13.41 \%)$ of 82 faecal samples were confirmed to be taeniasis by direct smears and copro-ELISA. All other samples $(\mathrm{n}=71)$ from direct smear negative were confirmed to be copro-ELISA negative. Taeniasis prevalence ranged from $25.6 \%(32 / 125)$ in 2002 , to $27.5 \%(14 / 51)$ in 2004 in Ketewel village, whereas prevalence was lower at $1.1 \%(1 / 94)$ in Jagapati village and 7.0\% (9/128) in Penatih village in 2004.

The number of $T$. saginata taeniasis cases was significantly higher in males $(82.1 \%$, 46/56) than in females $(17.9 \%, 10 / 56)$, respectively $(\mathrm{p}<0.01)$. Most of the $T$. saginata carriers were in the $30-44$ year age group $(51.8 \%, 29 / 56)$, followed by that of 45 years or older group $(30.4 \%, 17 / 56)$, and that of the $15-29$ year group $(17.8 \%, 10 / 56)$. The youngest T. saginata carrier was a 19 year old male and the oldest was a 70 year old male.

In Ketewel village, the number of families consuming raw beef (lawar) increased from $19.2 \%(14 / 73)$ in 2002 to $32.4 \%(12 / 37)$ in 2004 . When 32 taeniasis patients in this village, who expelled tapeworms after treatment with praziquantel in December 2002, were reexamined one year later (in February 2004), they all had no more history of additional expulsion of proglottids by QRDP and they all were direct smear negative.

Taeniid egg positive stool samples available $(n=10)$ and all proglottid samples from 56 tapeworm carriers were analyzed by copro-DNA and multiples PCR, respectively and all were confirmed to be $T$. saginata (data not shown). Additional mtDNA sequencing was carried out for 32 of 56 proglottid samples in order to re-confirm if they were really $T$. saginata or T. asiatica which might be distributed in Bali. All were re-confirmed to be $T$. saginata and no T. asiatica was found (sequencing data not shown). 
During 2002-2004, there was no person with indication of T. solium cysticercosis including history of epileptic seizures or presence of subcutaneous nodules except one seropositive against both $T$. solium GP antigens and a chimeric recombinant antigen in Ketewel in 2002 (data not shown). In this village, serological examination of 125 serum samples revealed that $1 / 125(0.8 \%)$ of sera was seropositive (a 76 years old male). There was no other seropositive cysticercosis case from all residents examined in 2004.

\subsection{Risk factors for $T$. saginata taeniasis}

Socio-economic data for 56 T. saginata taeniasis cases and 192 families showed that $87.5 \%(49 / 56)$ defecated in a toilet, while $12.5 \%(7 / 56)$ defecated in a river. No taeniasis carriers admitted to defecating in the space behind the house (teba). All taeniasis cases consumed raw pork and/or beef (lawar). Furthermore, 96.9\% (186/192) of families had a sanitary facility, and 3.1\% (6/192) defecated in a river. All pig owners (56 of 192 families) kept their pigs indoor. Five of 11 cattle owners kept their cattle in a fenced field, other cattle owners (6 families) kept their cattle in open common pasture. All families reported consumption of raw pork and/or beef.

During 2002-2004, we found that three of 56 taeniasis cases were lawar sellers, and had suffered from T. saginata taeniasis for 1-10 years. Several of the other taeniasis carriers also bought lawar from these sellers. Biviarate analyses of 106 family heads from endemic and non-endemic areas each in 2004 showed significant association of T. saginata taeniasis and level of education ( $\mathrm{p}<0.01)$, consumption of beaf lawar $(\mathrm{p}<0.01)$, and source of lawar $(\mathrm{p}<0.01)($ Table 2).

\section{Discussion}


According to National Socio-Economic Survey, 2003, the majority of the 3 million population of Bali is Hindu (Hindu 93.4 \%, Muslim 5.1 \%, Buddhist 0.5 \%, Protestant $0.5 \%$, Catholic $0.4 \%$ ) with a total population density of 585 per $\mathrm{km}^{2}$. The number of Muslims is however steadily increasing through immigration from Java, Lombok and other areas of Indonesia who seek work in Bali. Most people live in the coastal areas in the south, and the island's largest town and administrative center is located in Denpasar with a population of over 370,000 .

A total prevalence of $14.1 \%$ for T. saginata taeniasis was detected during 2002-2004 in two urban areas and one semi-urban area around Denpasar in Bali. Although sample collection was not completely random, it was suggested that the number of cases of $T$. saginata taeniasis had increased dramatically in Ketewel village compared with previous surveys in 1977 (2.1\%) and 1999 (1.3\%) (Simanjuntak et al., 1977; Sutisna et. al., 2000). Only seven T. saginata taeniasis cases were found in Gianyar District in 2002 (unpublished information from Gianyar District Health Office Services). Sutisna et al. (1999) reported that among 33 taeniasis patients in one village of Denpasar District, only $21.2 \%(7 / 33)$ visited the health facilities. These strongly suggest that such report was much lower than real prevalence through active case findings.

Several interesting questions still remain on the existence of taeniasis in Bali over the years. Previous surveys carried out in Gianyar, Badung, Denpasar Districts showed that the local people consumed pork more frequently than beef. However, T. saginata taeniasis was more common. It was suggested therefore that the taeniasis cases reported to be due to $T$. saginata might be caused by T. asiatica (Dharmawan, 1998; Sutisna et al., 1999; Ito et al., 2003, 2004). Based on the current study, however, there is no evidence for the existence of T. asiatica in human in Bali. We tried to get information on this issue from local people and got the information that they do not like the taste of uncooked viscera. This might be 
the reason why we cannot find any T. asiatica where local people like uncooked meat with blood as a traditional local dish (pork lawar) and T. solium cysticercosis cases are still sporadically found in Bali. This is thoroughly different from the ethnic Batak people in Samosir Island, North Sumatra who like the taste of uncooked viscera and where taeniasis of T. asiatica is still very common (Wandra et al., unpublished). Further surveys are necessary to get conclusion on this issue in different areas in Bali.

The number of cases with $T$. saginata taeniasis was higher in males than in females and most of the patients were in the 30-44 year age group. Similar findings were reported in Renon village, Denpasar and in other areas of Bali by Sutisna et al. (1999): In the traditional communities in villages, adult male groups often enjoy raw beef (lawar) with spirit/toddy (tuak). It is expected to be one of the factors why the number of cases in males is higher especially in the $30-40$ year age group.

Despite the fact that most Balinese people are Hindi, they do consume beef. In Ketewel village, the number of families consuming raw beef (lawar) increased from 19.2\% (14/73) in 2002 to $32.4 \%$ (12/37) of families in 2004 . There was no difference in the human taeniasis rate in $2002(25.6 \%, 32 / 125)$ and $2004(27.5 \%, 14 / 51)$ between several Banjars in Ketewel village. However, when 32 taeniasis patients in this village, who expelled tapeworm after treatment with praziquantel in December 2002, were re-examined one year later (in February 2004), there were no cases of re-infections with T. saginata. All of them reported and stressed that they stopped eating beef lawar anymore after they recognized that they harbored big tapeworms but few persons could not afford to stop eating beef lawar after one-three moths of the shocking evidence of expulsion of big tapeworms. This is a problem for control program especially for health education of these local people who like traditional local food. 
The source of infection for T. saginata taeniasis in the survey areas is not clear, and could be from other areas in Bali, since these survey areas are around Denpasar and semiurban areas, whereas most of the rest areas are rural and mountainous areas. According to unpublished information from Provincial Livestock Office Services in 2004, there is one slaughterhouse in Gianyar, Badung, Denpasar Districts. The personnel consisted of one veterinarian and one assistant veterinarian (mantri hewan) in each district. The number of livestock slaughtered ranged from 6-20 cattle/pigs per day in Gianyar, 20-21 in Badung, and 50-60 in Denpasar. However, many cattle/pigs from areas in Bali are also slaughtered in illegitimate slaughterhouses, and then distributed to the markets. The main problem is how to check the quality of beef/pork in these illegitimate slaughterhouses as well as the quality of meat hygiene in the markets.

The pork tapeworm T. solium now appears to be rare in Bali. Between 1975-2001, only six T. solium taeniasis carriers were detected (Simanjuntak et al., 1977; Sutisna 1989, 1990; Sutisna et al., 1999; Margono et al., 2004). Generally T. solium is rare in Indonesia as a whole because of Islam taboo on eating pork. However in a number of areas eg. Papua and Timor it is a public health problem, as it has previously been in Bali (Suroso, 2002; Margono et al., 2003, 2004; Wandra et al., 2003; Ito et al., 2003, 2004). Human cases of epileptic seizures in Balinese communities was reported to range from 1.1\%-8.0\% in Trunyan (Bangli District), Sukawati (Gianyar District) and Padangsambian (Badung District) in 1977 (Sutisna, 2002). At Wangaya Hospital in Denpasar, 68 and 368 new cases of epileptic seizures were reported in 1980 and 1984, respectively, whereas at Sanglah Hospital in Denpasar, 74 new cases were reported within 3 month in 1991 (Sutisna, 2002). Margono et al. (2001) reported that 10 of 74 (13.5\%) patients with epilepsy in Bali were diagnosed to be due to neurocysticercosis (NCC) based on ELISA serology (Margono et al., 2001). Both SCC and NCC cases were reported in Bali during 1960-1997 with the 
frequency of NCC cases approximately three times more than SCC cases (Ngoerah, 1975; Sutisna, 2002; Margono et al., 2004). Seroprevalence of cysticercosis in humans in Bali ranged from $5.2 \%$ up to $21 \%$ since more than 20 years ago (Coker-Vann et al., 1981). Another survey of 746 people revealed that 94 persons (12.6\%) were positive by the more specific glycoprotein immunoblot (Theis et al., 1994). A previous immunoblot survey for cysticercosis performed in Ketewel village revealed a seroprevalence of 5.2\% (6/115) (Sutisna et al., 2000).

In the current survey (2002-2004), there was no person detected in the community survey with a history of epileptic seizures or subcutaneous nodules, and only one cysticercosis case was diagnosed as seropositive (in Ketewel village)(data not shown).=

The apparent significant decrease in transmission of T. solium in Bali is probably due to improvement in sanitation and pig husbandry at least in urban and semi-urban areas where we did the field survey. In the surveyed areas, almost all families had sanitary facilities, and no person said that they defecated in the backyard (teba). In addition all pig owners interviewed kept their pigs indoors. By contrast, only $64.1 \%$ of families had sanitary facilities, while $42.4 \%$ of taeniasis carriers and $12.6 \%$ of families defecated in the backyard, and pigs were allowed to roam free in 1990 (Sutisna, 1990, 2002; Margono et al., 2004).

In conclusion, the current survey for human taeniasis and cysticercosis in Bali indicates that $T$. saginata taeniasis has increased in number of cases, while T. solium taeniasis and cysticercosis is now rather rare compared to 10-20 years ago. In order to control taeniasis/cysticercosis, several strategies have been proposed (Ito et al., 2003; Flisser et al., 2003; Gonzalez et al., 2003; Sarti et al., 2003; Schantz and Tsang, 2003). However, based on our survey results, (1) active case finding (active surveillance) and treatment of the tapeworm carriers, (2) check of beef lawar hygiene in the market including lawar sellers' health, periodically, (3) establishment of a system to check the quality of beef/pork and 
look for distribution of infected animals in Bali, and (4) sustainable public health education through treatment are expected to have the priorities.

We are planning to do similar work in other villages including western part of Bali and far north from Denpasar where traditional rural life style is still well conserved. Therefore, such areas are expected to be relatively high risk areas for both $T$. saginata in humans and cattle and T. solium in humans and pigs.

\section{Conflicts of interest statement.}

The authors have no conflicts of interest concerning the work reported in this paper.

\section{Acknowledgements}

We are grateful to all staffs, especially to Dr. H. Yamasaki, at Department of Parasitology, Asahikawa Medical College for technical assistance, and the Head and staffs of Department of Parasitology, University of Udayana, Sub-Directorate of Zoonosis, Directorate General CDC and EH, Ministry of Health, Indonesia, Bali Provincial Health Office Service, Gianyar, Badung and Denpasar Districts Health Office Service, Sukawati and East Denpasar Sub-Districts Health Centre, Penatih Village Office, Banjar Pamesan, Paang Kelod and Saba, and to John M. Saragih at National Institute of Health and Development, Ministry of Health for their cooperation and assistance during the field survey. This work was supported by Japan Society for Promotion of Science (JSPS) to A.I. (142560001, 17256002). T.W. is a Ronpaku researcher getting the JSPS scholarship from 2003. 


\section{References}

Allan, J.C., Craig, P.S., Garcia N.J., Mencos, F., Liu, D., Wang, Y., Wen, H., Zhou, P., Stringer, R., Rogan, M. et al., 1992. Coproantigen detection for immunodiagnosis of echinococcosis and taeniasis in dogs and humans. Parasitology 104, 347-356.

Coker-Vann, M.R., Subianto D.B., Brown P., Diwan, A.R., Desowitz, R., Garruto, R.M., Gibbs, C.J., Gaidusek, D.C. 1981. ELISA antibodies to cysticerci of Taenia solium in human populations in New Guinea, Oceania and Southeast Asia. S.E. Asian J. Trop. Med. Pub. Hlth. 12, 499-505.

Dharmawan, N.S., 1998. Histopathology of liver of pigs suspect infected with Taenia asiatica metacestode. Maj. Kedok Ud. 29, 187-192 (in Indonesia).

Eom, K.S., Rim, H.J. 1993. Morphologic descriptions of Taenia asiatica sp. n. Korean J. Parasitol. 31, 1-6.

Fan, P.C., 1988. Taiwan Taenia and taeniasis. Parasitol. Today 4, 86-88.

Flisser, A., Sarti, E., Lightowlers, M., Schantz, M., 2003. Neurocysticercosis: regional status, epidemiology, impact and control measure in the Americas. Acta Trop. 87, $43-51$

Gonzalez, A.E., Garcia, H.H., Gilman, R.H., Tsang, V.C.W., Cysticercosis working group in Peru., 2003. Control of Taenia solium. Acta Trop. 87, 103-109.

Handali, S., Liying, H., Lusikoy, C., Senis, K, Sihombing, D., 1997. A survey report - July 1993:Ccysticercosis in the Grand Dani valley, Jayawijaya district, Irian Jaya province, Indonesia. S.E. Asian J. Trop. Med. Pub. Hlth. 28 (suppl 1), 22-25.

Ito, A., Plancarte, A., Ma, L., Kong, Y., Flisser, A., Cho, Y.S., Liu, Y.H., Kamhawi, S., Lightowlers, M.W., Schantz, P.M., 1998. Novel antigen for neurocysticercosis: simple method for preparation and evaluation of serodiagnosis. Am. J. Trop. Med. Hyg. 59, 291-294. 
Ito, A., Plancarte, A., Nakao, M., Nakaya, K., Ikejima, T., Piao, Z.X., Kanazawa, T., Margono, S.S., 1999. ELISA and immunoblot using purified glycoproteins for serodiagnosis of cysticercosis in pigs naturally infected with Taenia solium. J. Helminth. 73, 363-365.

Ito, A., Wandra, T., Subahar, R., Hamid, A., Yamasaki, H., Mamuti, W., Okamoto, M., Nakaya, K., Nakao, M., Ishikawa, Y., Suroso, T., Craig, P.S., Margono, S.S., 2002. Recent advances in basic and applied science for the control of taeniasis/cysticercosis in Asia. S.E. Asian J. Trop. Med. Pub. Hlth. 33 (Suppl 3), 79-82.

Ito, A., Nakao, M., Wandra, T., 2003. Human taeniasis and cysticercosis in Asia. Lancet $362,1918-1920$.

Ito, A., Wandra, T., Yamasaki, H., Nakao, M., Sako, Y., Nakaya, K., Margono, S.S., Suroso, T., Gauci, C., Lightowlers, M.W., 2004. Cysticercosis/taeniasis in Asia and the Pacific. Vector-Borne Zoonotic Dis 4: 95-107.

Margono, S.S., Subahar, R., Hamid, A., Wandra, T., Raka Sudewi, S.S., Sutisna, P., Ito, A., 2001. Cysticercosis in Indonesia: epidemiological aspects. S.E. Asian J. Trop. Med. Pub. Hlth. 32 (Suppl 2):79-84.

Margono, S.S., Ito, A., Sato, M.O., Okamoto, M., Subahar, R., Yamasaki, H., Hamid, A., Wandra, T., Purba, W.H., Nakaya, K., Ito, M., Craig, P.S., Suroso, T., 2003. Taenia solium taeniasis/cysticercosis in Papua, Indonesia in 2001: detection of human worm carriers. J. Helminthol. 77, 39-42.

Margono, S.S., Wandra, T., Suroso, T., Ito, A., 2004. Taeniasis and cysticercosis in Indonesia. In: Ito, A., Wen, H., Yamasaki, H. (Eds.), Taeniasis/Cysticercosis and Echinococcosis in Asia. Asian Parasitology vol. 2, AAA Committee/Federation of Asian Parasitologists, Chiba, Japan, pp. 115-134. 
Nakao, M., Okamoto, M., Sako, Y., Yamasaki, H., Nakaya, K., Ito, A., 2002. A phylogenic hypothesis for the distribution of two genotypes of the pork tapeworm Taenia solium worldwide. Parasitology 124, 657-662.

Ngoerah, I.G.N.G., 1975. Cysticercosis of the central nervous system. Maj. Ilmiah Univ. Udayana 31-38 (in Indonesia).

Sako, Y., Nakao, M., Ikejima, T., Piao, X.Z., Nakaya, K., Ito, A., 2000. Molecular characterization and diagnostic value of Taenia solium low-molecular-weight antigen gene. J. Clin. Microbiol. 38, 4439-4444.

Sarti, E., Rajsekhar, V., 2003. Measures for the prevention and control of Taenia solium taeniosis and cysticercosis. Acta Trop. 87, 137-143.

Schantz, P.M., Tsang, V.C.W., 2003. The US Centers for disease control and prevention (CDC) and research and control of cysticercosis. Acta Trop. 87, 161-163.

Simanjuntak, G.M., Margono, S.S., Sachlan, R., Harjono, C., Rasidi, R., Bambang Sutopo., 1977. An investigation on taeniasis and cysticercosis in Bali. S.E. Asian J. Trop. Med. Pub. Hlth. 8, 494-497.

Simanjuntak GM, Margono SS, Okamoto M, Ito A. Taeniasis/cysticercosis in Indonesia as an emerging disease. Parasitol. Today 1997; 13: 321-323.

Suroso T., 2002. Guidelines for Taeniasis/Cysticercosis Control in Indonesia. Communicable Disease Control and Environmental Health, Ministry of Health, Indonesia. pp. 1-30 (in Indonesia).

Sutisna, P., 1989. Parasitic infections in humans in Bali: a review. Bull. Pen. Kes. 17, 276283.

Sutisna, P., 1990. The problem of taeniasis in Banjar Kelod, Renon, Denpasar. Medika 7, 543-549 (in Indonesia). 
Sutisina, P., 2002. Problem of taeniasis/cysticercosis in Indonesia: Epidemiological and preventional aspects. Scientific Presentation for New Professorship at Faculty of Medicine, University of Udayana, pp. 1-23 (in Indonesia).

Sutisna, P., Flaser, A., Kapti, I.N., Rodriguez-Canul, R., Puta Widjana, D., Craig, P.S., Allan, J.C., 1999. Community prevalence study of taeniasis and cysticercosis in Bali, Indonesia. Trop. Med. Int. Hlth. 4, 288-294.

Sutisna, P., Kapti, I.N., Allan, J.C., Rodriguez-Canul, R., 2000. Prevalence of taeniasis and cysticercosis in Banjar Pamesan, Ketewel Village, Gianyar, Bali. Maj. Kedok Ud. 31, 226-234 (in Indonesia).

Suweta, I.G., 1991. The situation of cysticercosis/taeniasis in animal $/ \mathrm{man}$ in Bali. S.E. Asian J. Trop. Med. Pub. Hlth. 22(suppl), 236-238.

Theis, J.H., Goldsmith, R.S., Flisser, A., Koss, J., Chionino, C., Plancarte, A., Segura, A., Widjana, D., Sutisna, P., 1994. Detection by immunoblot assay of antibodies to Taenia solium cysticerci in sera from residents of rural communities and from epileptic patients in Bali, Indonesia. S.E. Asian J. Trop. Med. Pub. Hlth. 25, 464-468. Wandra, T., Subahar, R., Simanjuntak, G.M., Margono, S.S., Suroso, T., Okamoto, M., Nakao, Y., Nakaya, K., Schantz, P.M., Ito, A., 2000. Resurgence of cases of epileptic seizures and burns associated with cysticercosis in Assologaima, Jayawijaya, Irian Jaya, Indonesia, 1990-1995. Trans. R. Soc. Trop. Med. Hyg. 94, 46-50.

Wandra, T., Ito, A., Yamasaki, H., Suroso, T., Margono, S.S., 2003. Taenia solium cysticercosis, Irian Jaya, Indonesia. Emerg. Infect. Dis. 9, 884-885.

Yamasaki, H., Allan, J.C., Sato, M.O., Nakao, N., Sako, Y., Nakaya, K., Qiu, D., Mamuti, W., Craig, P.S., Ito, A., 2004a. DNA differential diagnosis of taeniasis and cysticercosis by multiplex PCR. J. Clin. Microbiol. 42, 548-553. 
Yamasaki, H., Matsunaga, S., Yamamura, K., Chang, C.C., Kawamura, S., Sako, Y., Nakao, M., Nakaya, K., Ito, A., 2004b. Solitary neurocysticercosis case caused by Asian genotype of Taenia solium confirmed by mitochondrial DNA analysis. J. Clin. Microbiol. 42, 3891-3893.

Yamasaki, H., Allan, J.C., Sato, M.O., Nakao, M., Sako, Y., Nakaya, K., Mamuti, W., Craig, P.S., Ito, A., 2004c. Multiplex PCR diagnosis for taeniasis and cysticercosis. Southeast Asian J. Trop. Med. Pub. Health 35 (Suppl 1), 275-279. 
Table 1 Number of Taenia saginata taeniasis cases detected by anamnesis and stool examination by either direct smear or copro-ELISA test in urban and semi-urban areas in Bali, 2002 and 2004

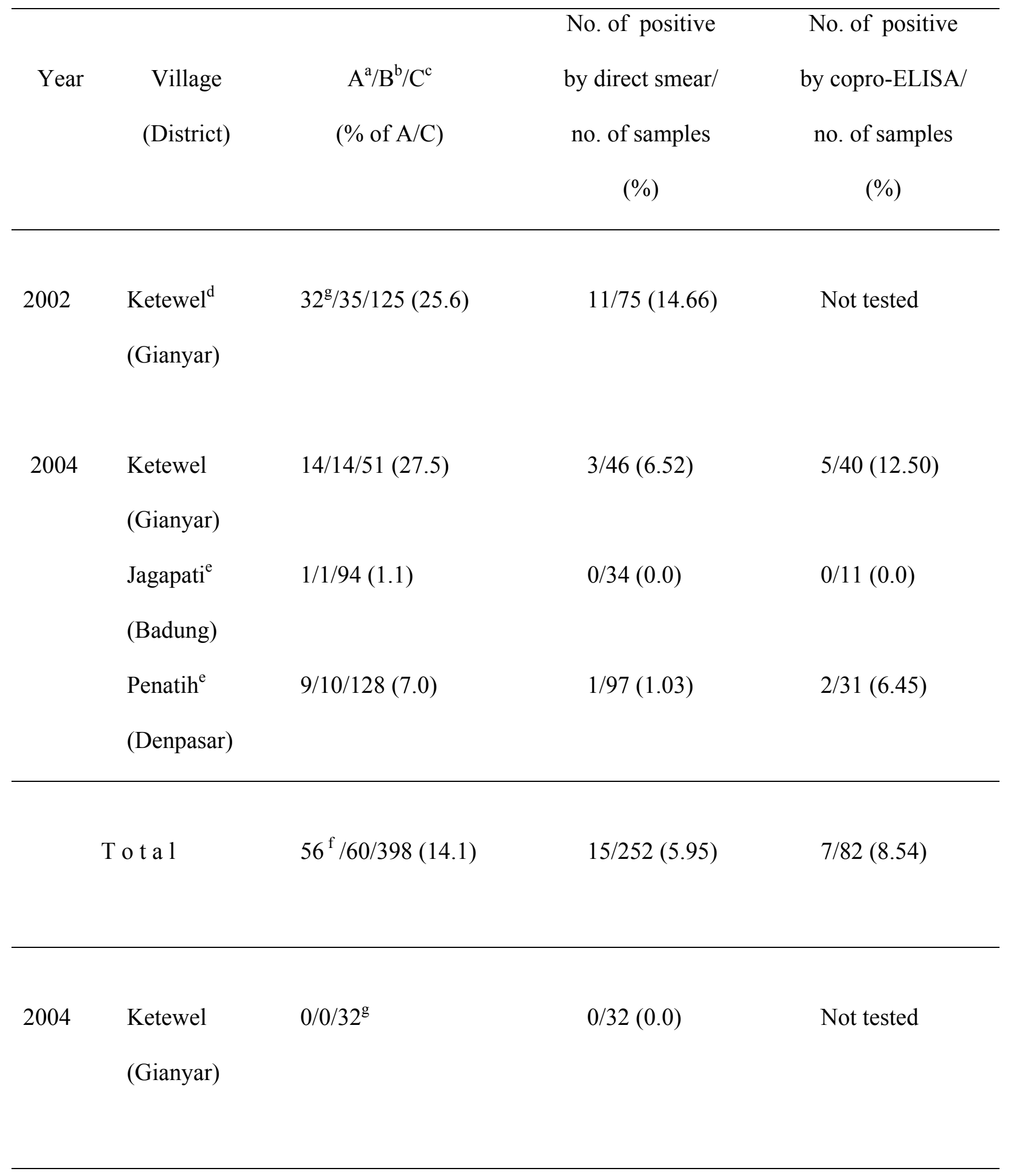

${ }^{a}$ No. of persons who expelled taeniid tapeworms 
${ }^{\mathrm{b}}$ No. of suspected taeniasis persons through QRDP

${ }^{\mathrm{c}}$ No. of residents examined

${ }^{\mathrm{d}}$ Semi-urban area

${ }^{\mathrm{e}}$ Urban areas

${ }^{\mathrm{f}} 56$ persons expelled a total of 61 taeniid adult worms after praziquantel treatment $(15 \mathrm{mg} / \mathrm{kg})$.

${ }^{g}$ Persons who expelled tapeworm after treatment with praziquantel in December 2002 and were reexamined one year later in February 2004. 
Table 2 Risk factors associated with Taenia saginata taeniasis in the communities (2004)

\begin{tabular}{|c|c|c|c|c|c|}
\hline \multirow{3}{*}{ Variables } & \multirow{2}{*}{\multicolumn{2}{|c|}{$\begin{array}{l}\text { Endemic area }^{a} \\
(\mathrm{n}=106)\end{array}$}} & \multicolumn{2}{|c|}{ Non-endemic area } & \multirow{3}{*}{$\mathrm{p}$} \\
\hline & & & & & \\
\hline & $\mathrm{n}$ & $\%$ & $\mathrm{n}$ & $\%$ & \\
\hline \multicolumn{6}{|l|}{ Levels of education } \\
\hline Low $^{c}$ & 62 & 59.0 & 33 & 31.1 & $<0.01$ \\
\hline Middle and/or High ${ }^{\mathrm{d}}$ & 44 & 41.0 & 73 & 68.9 & \\
\hline \multicolumn{6}{|c|}{ Consumption of beef lawar } \\
\hline Yes & 63 & 59.4 & 37 & 35.0 & $<0.01$ \\
\hline No & 43 & 40.6 & 69 & 65.0 & \\
\hline \multicolumn{6}{|c|}{ Source of lawar (beef and/or pork) } \\
\hline Market & 55 & 51.9 & 30 & 28.0 & $<0.01$ \\
\hline Home made & 51 & 48.1 & 76 & 72.0 & \\
\hline
\end{tabular}

a: Banjar Saba, Banjar Pamesan and its surroundings, Sukawati Sub-District, Gianyar.

b: Banjar Paang Kelod, East Denpasar Sub-District, Denpasar.

${ }^{c}$ : No formal school education or only primary school.

d: Junior/senior high school (middle), Academy/university (high). 